\title{
Salinity-Induced Changes of Photosynthetic Performance, Lawsone, VOCs, and Antioxidant Metabolism in Lawsonia inermis L.
}

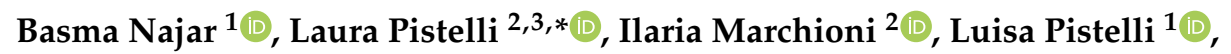 \\ Beatrice Muscatello ${ }^{1}$, Marinella De Leo ${ }^{1}$ (D) and Andrea Scartazza ${ }^{4}$ (D) \\ 1 Department of Pharmacy, University of Pisa, 56124 Pisa, Italy; Basmanajar@hotmail.fr (B.N.); \\ Luisa.pistelli@unipi.it (L.P.); Beatrice.muscatello@unipi.it (B.M.); Marinella.deleo@unipi.it (M.D.L.) \\ 2 Department of Agriculture, Food and Environment (DAFE), University of Pisa, 56124 Pisa, Italy; \\ i.marchioni@studenti.unipi.it \\ 3 Centre for Climate Change Impact (CIRSEC), University of Pisa, 56124 Pisa, Italy \\ 4 Research Institute on Terrestrial Ecosystems, Research National Council, 56124 Pisa, Italy; \\ andrea.scartazza@cnr.it \\ * Correspondence: Laura.pistelli@unipi.it; Tel.: +39-050-2216536
}

Received: 21 November 2020; Accepted: 15 December 2020; Published: 18 December 2020

\begin{abstract}
The present study aimed to elucidate the salinity influence on the bioactive metabolites of Lawsonia inermis L. (henna) plants. Young henna plants were cultivated under salinity stress with two $\mathrm{NaCl}$ concentrations $(75 \mathrm{mM}$ and $150 \mathrm{mM}$ ) in controlled environmental conditions and the leaves were investigated to check their adaptative responses. The modulation of photosynthetic performance to salinity stress was demonstrated by gas exchange and chlorophyll fluorescence parameters. The partial stomatal closure triggered an enhanced water-use efficiency, and a proline accumulation was observed, leading to an osmotic adjustment. The increased capacity to dissipate the excess excitation energy at photosystem II as heat was associated with changes in chlorophylls, anthocyanins, and carotenoids. The higher antioxidant activity at $150 \mathrm{mM}$ salt level suggested its scavenger role on reactive oxygen species (ROS) dissipation and photoprotection. The reduced $\mathrm{CO}_{2}$ uptake and the higher metabolic costs necessary to sustain the henna tolerance mechanism against high $\mathrm{NaCl}$ concentration negatively affected lawsone production. Leaf volatile organic compounds (VOCs) showed changes in the amount and composition of VOCs with increasing salinity level. Overall, this study revealed efficient physiological and biochemical adaptations of henna leaves to salt stress despite an altered production of important economic metabolites such as lawsone.
\end{abstract}

Keywords: henna; abiotic stress; gas exchange parameters; photosynthesis; proline; antioxidant metabolites; dye compound

\section{Introduction}

Lawsonia inermis L., commonly known as henna (Arabic), is a native plant of North Africa and Southwest Asia [1] that belongs to the Lythraceae family. Henna has been used cosmetically and medicinally for over 9000 years; its leaves contain different bioactive compounds, mainly alkaloids, phenols, steroids, and terpenes [1-4]. These compounds are known to have a wide range of biological properties such as antifungal, antibacterial, and antioxidant activities [5]. Henna is used worldwide as a cosmetic agent to stain hair, skin, and nails [2]. This use is due to the presence of lawsone (2-hydroxy-1,4-naphthoquinone), also known as hennotannic acid, a red-orange dye present in the leaves at a concentration of $1.0-1.4 \% w / w$ [5], with coloring and pharmacological activity. Lawsone is present only in the leaves and its concentration depends on climatic conditions. The cultivation of 
henna as a common hedge occurs in tropical and also arid areas characterized by very dry climatic conditions. In fact, henna plants perish at temperatures below $5{ }^{\circ} \mathrm{C}$, and the reproduction phase is inhibited below $11^{\circ} \mathrm{C}$ [6], while the dye compound is mainly produced between 35 and $45^{\circ} \mathrm{C}$.

Several studies have been carried out to underline the effect of some abiotic factors on germination, seedling growth, and morphological and physiological traits $[7,8]$. Drought stress is considered one of the main limiting factors of the henna cultivation that alters the growth, gas exchange parameters, and photosynthetic pigment contents proportionally with the intensity of water limitation $[7,9]$. L. inermis can overcome drought stress but not salinity [6] because it activates the reproductive phase when subjected to prolonged salt stress [10]. Nevertheless, the influence of salt stress on the lawsone production has not yet been determined. Bakkali and co-workers suggested that lawsone biosynthesis is affected by a complex control mechanism [11], and roots could play a role in the naphthoquinone biosynthesis. Therefore, the salinity treatment induced in the roots can contribute to changing the content of lawsone and other metabolites. It is well known that high levels of salinity induce generation of reactive oxygen species (ROS) that contribute to changes in membrane peroxidation [12]. In a recent paper [8], the positive effect of salicylic acid treatment emerged in terms of improving resistance to short-term salinity stress on young henna plants, with an activation of the antioxidant defense system through an increase in catalase activity.

Salt stress may also affect the essential oil (EO) production and composition in association with changes in enzymatic activity and alteration of intermediary products available during stress [13]. The influence of several environmental conditions on the emitted volatile organic compounds (VOCs) has been demonstrated on several medicinal and aromatic plants such as Foeniculum vulgare, Majorana hortensis, Thymus vulgaris, Catharanthus roseus, Nigella sativa, Matricaria chamomilla, Salvia dolomitica, and Helicrysum petiolare [13,14]. However, to the best of our knowledge, data concerning VOC production in L. inermis under salt stress are missing.

The aims of this paper were (i) to investigate the mechanism of stress tolerance to salt stress through the physiological and biochemical adaptations in henna plants grown for 20 days at increasing salinity levels, and (ii) to evaluate the effect of these adaptation mechanisms on plant growth, aroma compounds, and lawsone production.

\section{Results}

\subsection{Morphological Parameters}

The effects of salt treatments $(75 \mathrm{mM}$ and $150 \mathrm{mM} \mathrm{NaCl})$ on the growth of henna plants were investigated at $0,3,10$, and 20 days after treatment (DAT) (Table 1). The prolonged salt treatment pointed out the difference on plant growth correlated to the concentration of salt. Although the leaf number of henna was higher in control than in the treated plants, at $10 \mathrm{DAT}$, the discrepancy disappeared.

Table 1. The influence of salt treatments $(0,75$, and $150 \mathrm{mM} \mathrm{NaCl})$ on leaf area and leaf number per plant determined during the growth of Lawsonia inermis. Relative water content (RWC, \%) was determined at the end of treatment. Values are means \pm Standard Error (SE) $(n=9)$. Different letters indicate statistically significant differences with Fisher's probable least-squares difference test $(p \leq 0.05)$.

\begin{tabular}{cccc}
\hline & Control 0 $\mathbf{~ m M}$ & $\mathbf{7 5 ~} \mathbf{~ M ~ N a C l}$ & $\mathbf{1 5 0 ~} \mathbf{~ M ~ N a C l}$ \\
\hline Leaf number (0 DAT) & $11.1 \pm 0.69^{\mathrm{b}}$ & $9.5 \pm 1.4^{\mathrm{a}}$ & $9.5 \pm 0.69^{\mathrm{a}}$ \\
Leaf number (3 DAT) & $11.25 \pm 0.65^{\mathrm{b}}$ & $10.75 \pm 0.53^{\mathrm{ab}}$ & $10 \pm 0.38^{\mathrm{a}}$ \\
Leaf number (10 DAT) & $14.62 \pm 0.65^{\mathrm{ab}}$ & $16.62 \pm 1.18^{\mathrm{b}}$ & $13.87 \pm 0.67^{\mathrm{a}}$ \\
Leaf number (20 DAT) & $21.5 \pm 1.46^{\mathrm{b}}$ & $19.87 \pm 1.43^{\mathrm{ab}}$ & $15 \pm 0.54^{\mathrm{a}}$ \\
Leaf area (10 DAT, cm $\mathrm{cm}^{2}$ plant) & $3.272 \pm 0.446^{\mathrm{b}}$ & $2.906 \pm 0.22^{\mathrm{ab}}$ & $2.089 \pm 0.259^{\mathrm{a}}$ \\
Leaf area (20 DAT, cm $\mathrm{cm}^{2}$ plant) & $4.845 \pm 0.616^{\mathrm{b}}$ & $4.622 \pm 0.203^{\mathrm{b}}$ & $2.744 \pm 0.163^{\mathrm{a}}$ \\
RWC (20 DAT, \%) & $80.29 \pm 2.84^{\mathrm{b}}$ & $71.63 \pm 2.61^{\mathrm{a}}$ & $74.35 \pm 2.17^{\mathrm{ab}}$ \\
\hline
\end{tabular}


At 10 DAT, the $150 \mathrm{mM}$ plants showed the lowest leaf number (13.87), while the control and $75 \mathrm{mM}$ plants showed a higher number of leaves (14.62 and 16.62, respectively). At the end of treatment, the statistical difference was confirmed, and the number of leaves of the highest salt concentration was found to be lower than the other treatments.

The leaf area differed between and during the duration of treatments (Table 1). At 10 DAT, the highest salt concentration triggered a lower leaf area than that of the control. At the end of the treatment (20 DAT), the leaf area at $150 \mathrm{mM} \mathrm{NaCl}$ was about half that of the control, while $75 \mathrm{mM}$ plants had values that were more linked to the control $\left(2.744,4.845\right.$, and $\left.4.622 \mathrm{~cm}^{2}\right)$.

At the end of treatment (20 DAT), the Relative Water Content (RWC) was determined, showing a lower percentage of water in $75 \mathrm{mM}$ salt-stressed plants $(71.63 \%)$ compared to the control $(80.29 \%)$, followed by those at $150 \mathrm{mM}(74.35 \%)$ (Table 1$)$.

\subsection{Effects of Salt Treatment on Chlorophyll Fluorescence Parameters and Leaf Gas Exchanges}

The effects of salt treatments $(75 \mathrm{mM}$ and $150 \mathrm{mM} \mathrm{NaCl})$ on photosynthetic-related parameters were monitored by chlorophyll fluorescence and leaf gas exchange measurements at $0,3,10$, and 20 days after treatment (DAT) (Figure 1). The analysis of the fluorescence of chlorophyll $a$ showed significant difference in $\Phi_{\text {PSII }}$ and non-photochemical quenching (NPQ) only at 20 DAT of the highest salt treatment, while $\mathrm{F}_{\mathrm{v}} / \mathrm{F}_{\mathrm{m}}$ remained unchanged throughout the treatment period (Figure $1 \mathrm{~A}-\mathrm{C}$ ). In detail, at $20 \mathrm{DAT}$, plants treated with $150 \mathrm{mM} \mathrm{NaCl}$ showed a significant reduction of $\Phi_{\mathrm{PSII}}$ associated with an increase in NPQ, while plants treated with $75 \mathrm{mM} \mathrm{NaCl}$ did not show any significant changes of the fluorescence parameters with respect to control throughout the treatment period.
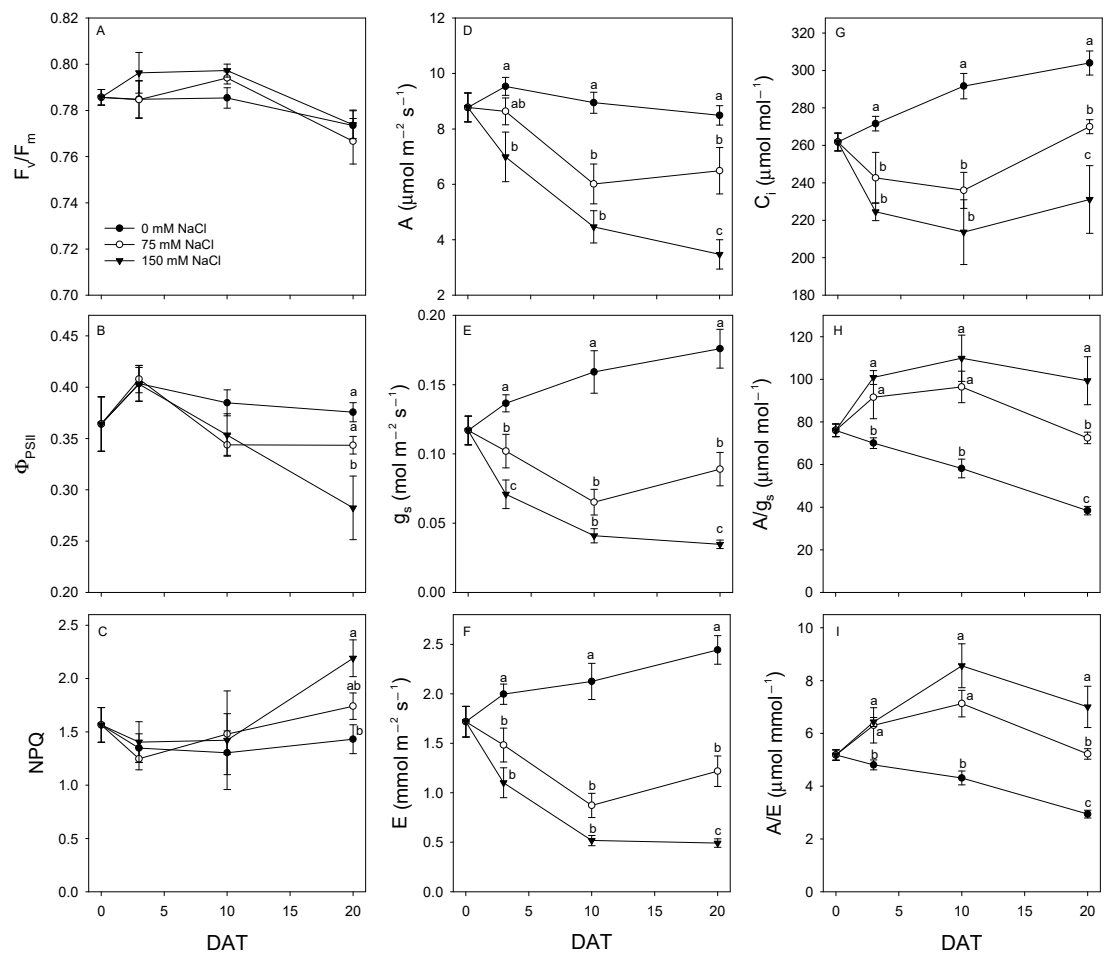

Figure 1. Variations of (A) potential efficiency of photosystem II (PSII) photochemistry $\left(\mathrm{F}_{\mathrm{v}} / \mathrm{F}_{\mathrm{m}}\right)$, (B) actual photon yield of PSII photochemistry $\left(\Phi_{\mathrm{PSII}}\right),(\mathrm{C})$ non-photochemical quenching $(\mathrm{NPQ})$, (D) $\mathrm{CO}_{2}$ assimilation rate, (E) stomatal conductance $\left(\mathrm{g}_{\mathrm{s}}\right)$, (F) transpiration rate, $(\mathrm{G})$ intercellular $\mathrm{CO}_{2}$ concentration $\left(\mathrm{C}_{\mathrm{i}}\right),(\mathbf{H})$ intrinsic water-use efficiency $\left(\mathrm{A} / \mathrm{g}_{\mathrm{s}}\right)$, and $(\mathbf{I})$ instantaneous water-use efficiency $(\mathrm{A} / \mathrm{E})$ at $0,3,10$, and 20 days after treatment (DAT) with 0,75 , and $150 \mathrm{mM} \mathrm{NaCl}$. Values are means $\pm \mathrm{SE}$ ( $n=6-9)$. Different letters indicate significant differences among treatments $(p \leq 0.05$, Fisher's Least Significant Difference, LSD). 
Figure 1D-I shows the variations of $A, g_{s}, E, C_{i}$, intrinsic water-use efficiency (WUE) (i.e., $A / g_{s}$ ), and instantaneous WUE (i.e., A/E) during the treatment period. Plants treated with $150 \mathrm{mM} \mathrm{NaCl}$ showed a lower A compared to control only after 3 days of treatment, while those treated with $75 \mathrm{mM}$ $\mathrm{NaCl}$ were not significantly affected by the treatment until 10 DAT. At 3 DAT, a decrease of $\mathrm{g}_{\mathrm{s}}$ occurred at both the $\mathrm{NaCl}$ concentrations, although the stomatal closure was more marked in plants treated with the highest salt dose. The gas exchange parameters $C_{i}$ and $E$ showed a similar decrease in both salt treatments at 3 DAT, while A/gs and A/E significantly increased compared to the control. After 10 days of salt treatment, a similar decrease of $\mathrm{A}, \mathrm{g}_{\mathrm{s}}, \mathrm{C}_{\mathrm{i}}$, and $\mathrm{E}$ was observed at both salt concentrations compared to the control, while $\mathrm{A} / \mathrm{g}_{\mathrm{s}}$ and $\mathrm{A} / \mathrm{E}$ were significantly higher in salt-treated plants than in the control. At 20 DAT, a dose-dependent reduction of $\mathrm{A}, \mathrm{g}_{\mathrm{s}}, \mathrm{C}_{\mathrm{i}}$, and $\mathrm{E}$ was observed in salt-treated plants compared to the control, with the lowest values for all these gas exchange parameters recorded in plants treated with the highest $\mathrm{NaCl}$ concentration. Conversely, $\mathrm{A} / \mathrm{g}_{\mathrm{s}}$ and $\mathrm{A} / \mathrm{E}$ were maintained significantly higher in salt-treated plants than in the control, especially at the highest $\mathrm{NaCl}$ concentration.

\subsection{Biochemical Analyses}

Analyses of several metabolites were performed at 20 DAT (Table 2). The salinity produced different effects on photosynthetic pigments, which were measured per area of fresh leaves. The amount of chlorophyll $b$ and $a$ was significantly higher at the highest $\mathrm{NaCl}$ concentration $\left(6.7\right.$ and $20.95 \mathrm{mg} \mathrm{cm}^{-2}$ per $150 \mathrm{mM}$, respectively) in comparison with the other plants ( 3.7 and $12.47 \mathrm{mg} \mathrm{cm}^{-2}$, respectively, in control vs. 5.22 and $15.68 \mathrm{mg} \mathrm{cm}^{-2}$, respectively, at $75 \mathrm{mM}$ ). Therefore, the total chlorophyll amount gradually increased with the salinity $\left(16.17,20.9\right.$, and $27.65 \mathrm{mg} \mathrm{cm}^{-2}$ for control, $75 \mathrm{mM}$, and $150 \mathrm{mM}$ $\mathrm{NaCl}$, respectively). However, the ratio of chlorophyll $a /$ chlorophyll $b$ showed a decrease in the salinity treatment. The total carotenoid content showed an increased concentration in the presence of the highest salt level, reaching a 1.5-fold value of the other salt level $\left(5.2,5.86\right.$, and $7.4 \mathrm{mg} \mathrm{cm}^{-2}$ for control, $75 \mathrm{mM}$, and $150 \mathrm{mM} \mathrm{NaCl}$, respectively). Anthocyanin pigments followed a similar trend of carotenoids; the highest value (48.96 $\mathrm{mg} \mathrm{g}^{-1}$ Fresh Weight, FW) was detected in $150 \mathrm{mM}$ henna plants, while a lower concentration of salt did not produce a significant difference in comparison with the control (34.53 and $29.53 \mathrm{mg} \mathrm{g}^{-1} \mathrm{FW}$, respectively; Table 2). Anthocyanins are chemically ascribed as the main class flavonoids, and the total amount of these metabolites increased with the $\mathrm{NaCl}$ concentration, with a 1.5-fold higher amount in $150 \mathrm{mM}$ leaves in comparison with the control (551.52 and $375.82 \mathrm{mg} \mathrm{g}^{-1} \mathrm{FW}$, respectively).

The salt stress is often associated with oxidative stress, and therefore the antioxidant activity was determined as radical scavenger activity of 2,2-diphenyl-1-picrylhydrazyl radical (DPPH) using the $\mathrm{IC}_{50}$ values. The DPPH assay was higher in the leaves of plants treated with $150 \mathrm{mM} \mathrm{NaCl}$, which exhibited the highest value of fresh leaves reducing $50 \%$ of DPPH $\left(16.07 \mathrm{mg} \mathrm{mL}^{-1}\right)$, while the lower activity was detected in the control $\left(24.51 \mathrm{mg} \mathrm{mL}^{-1}\right)$, and the $75 \mathrm{mM} \mathrm{NaCl}$ showed a medium level of activity $\left(19.72 \mathrm{mg} \mathrm{mL}^{-1}\right.$ ). Using a different antioxidant test (ferric ion reducing antioxidant power (FRAP) assay), we found that the obtained values confirmed the increased antioxidant activity with the increase of salt concentration. Polyphenols are considered a class of metabolites involved in several stress conditions, but the influence of salt stress in L. inermis leaves did not include changes in their levels, since no significant difference was demonstrated (Table 2). The salinity showed an increase in proline content. Control leaves showed the lowest amount $\left(70.16 \mathrm{mg} \mathrm{g}^{-1} \mathrm{FW}\right)$, and the highest amount (statistically different) was detected in $150 \mathrm{mM}\left(91.3 \mathrm{mg} \mathrm{g}^{-1} \mathrm{FW}\right)$. 
Table 2. Determination of pigments, secondary metabolites, and radical scavenger activity in the Lawsonia inermis leaves after treatment with different $\mathrm{NaCl}$ concentrations $(0,75$, and $150 \mathrm{mM})$. Data are presented as means \pm SE $(n=3)$. Different letters indicate statistically significant differences with Fisher's probable least squares difference test $(p \leq 0.05)$. Abbreviations: GAE—gallic acid equivalents; $\mathrm{CE}$-catechin equivalents; $\mathrm{ME}$-malvin hloride equivalents.

\begin{tabular}{|c|c|c|c|}
\hline & Control $0 \mathrm{mM}$ & $75 \mathrm{mM} \mathrm{NaCl}$ & $150 \mathrm{mM} \mathrm{NaCl}$ \\
\hline Chlorophyll $a$ (Chla, $\left.\mu \mathrm{g} \mathrm{cm}^{-2} \mathrm{FW}\right)$ & $12.47 \pm 0.56^{\mathrm{a}}$ & $15.68 \pm 1.17^{\mathrm{a}}$ & $20.95 \pm 0.28^{b}$ \\
\hline Chlorophyll $b$ (Chlb, $\left.\mu \mathrm{g} \mathrm{cm}^{-2} \mathrm{FW}\right)$ & $3.70 \pm 0.43^{a}$ & $5.22 \pm 0.36^{\mathrm{ab}}$ & $6.7 \pm 0.52^{b}$ \\
\hline Total chlorophyll (Tchl, $\left.\mu \mathrm{g} \mathrm{cm}^{-2} \mathrm{FW}\right)$ & $16.17 \pm 0.89^{a}$ & $20.9 \pm 1.46^{b}$ & $27.65 \pm 0.39^{c}$ \\
\hline Ratio Chla/Chlb & $3.45 \pm 0.38^{b}$ & $3.01 \pm 0.16^{\mathrm{a}}$ & $3.17 \pm 0.26^{\mathrm{ab}}$ \\
\hline Total carotenoids (Tcar, $\mu \mathrm{g} \mathrm{cm}^{-2} \mathrm{FW}$ ) & $5.2 \pm 0.22^{a}$ & $5.86 \pm 0.5^{\mathrm{a}}$ & $7.4 \pm 0.33^{b}$ \\
\hline Ratio Tcar/Tchl & $0.32 \pm 0.009^{b}$ & $0.28 \pm 0.004^{a}$ & $0.267 \pm 0.008^{a}$ \\
\hline Proline $\left(\mathrm{mg} \mathrm{g}^{-1} \mathrm{FW}\right)$ & $70.16 \pm 7.78^{a}$ & $76.08 \pm 3.68^{a b}$ & $91.3 \pm 4.67^{b}$ \\
\hline Total polyphenols (TP, mg GAE g $\left.{ }^{-1} \mathrm{FW}\right)$ & $839.77 \pm 55.598^{a}$ & $755 \pm 27.7^{a}$ & $795.49 \pm 26.86^{\mathrm{a}}$ \\
\hline Total flavonoids (TF, $\left.\mathrm{mg} \mathrm{CE} \mathrm{g}^{-1} \mathrm{FW}\right)$ & $375.82 \pm 27.92^{a}$ & $448.48 \pm 30.12^{a b}$ & $551.52 \pm 65.28^{b}$ \\
\hline Total anthocyanins ( $\left.\mathrm{mg} \mathrm{ME} \mathrm{g}^{-1} \mathrm{FW}\right)$ & $29.35 \pm 0.42^{a}$ & $34.53 \pm 1.21^{a}$ & $48.96 \pm 5.52^{b}$ \\
\hline $\begin{array}{l}\text { Radical scavenging assay } \\
\left(\mathrm{DPPH}-\mathrm{IC}_{50} \mathrm{mg} \mathrm{mL}^{-1}\right)\end{array}$ & $24.51 \pm 3.09^{b}$ & $19.72 \pm 0.05^{\mathrm{ab}}$ & $16.072 \pm 0.22^{a}$ \\
\hline $\begin{array}{l}\text { Antioxidant activity-FRAP assay } \\
\left(\mathrm{mmol} \mathrm{Fe}^{2+} \mathrm{g}^{-1} \mathrm{FW}\right)\end{array}$ & $44.66 \pm 1.71^{a}$ & $52.67 \pm 1.74^{\mathrm{ab}}$ & $58.66 \pm 4.30^{b}$ \\
\hline
\end{tabular}

\subsection{Lawsone Production}

Results about lawsone extraction from plants subjected to control $(0 \mathrm{NaCl})$ and saline stress (75 and $150 \mathrm{mM} \mathrm{NaCl}$ ) are reported in Table 3. The extraction process was not highly selective, and thus other high polar molecules were also concurrently extracted. The yield of the control plant extraction was much higher than that obtained from the treated plant extractions. Lawsone was detected and quantified in all the samples by liquid chromatography (LC)-photo diode array (PDA)/ultraviolet (UV)-electrospray ionization (ESI)-tandem mass spectrometry (MS/MS) analyses. The presence of lawsone was confirmed in all the extracts, comparing its UV and mass spectra with those of a reference standard. UV spectra were characterized by three absorptions at 248, 289, and $333 \mathrm{~nm}$. In the full mass spectrum, the deprotonated molecule $[\mathrm{M}-\mathrm{H}]^{-}$was detected at $m / z 173$, while the fragmentation pattern showed a diagnostic product ion at $\mathrm{m} / \mathrm{z} 145$ due to the neutral loss of a CO molecule $[\mathrm{M}-\mathrm{H}-28]^{-}$. The lawsone amount (Table 3), expressed as milligram of compound in $1 \mathrm{~g}$ of fresh material, differed among the analyzed samples when compared to the control (5.90 $\left.\mathrm{mg} \mathrm{g}^{-1} \mathrm{FW}\right)$. Notably, both saline treatments (75 and $150 \mathrm{mM}$ ) induced a significant decrease (about $77 \%$ and $80 \%$, respectively) in term of lawsone amount.

Table 3. Results of the lawsone extraction process and its quantitative analyses in Lawsonia inermis aerial parts subjected to control $(0 \mathrm{NaCl})$ and saline treatments $(75$ and $150 \mathrm{mM} \mathrm{NaCl})$. Data are presented as means $\pm \mathrm{SD}(n=3)$. Different letters indicate statistically significant differences with Fisher's probable least-squares difference test $(p \leq 0.05)$.

\begin{tabular}{|c|c|c|c|}
\hline Treatment & $\begin{array}{l}\text { Starting Dried } \\
\text { Aerial Parts (g) }\end{array}$ & $\begin{array}{c}\text { Yield of the } \\
\text { Extraction Process (g) }\end{array}$ & $\begin{array}{c}\text { Lawsone } \\
\left(\mathrm{mg} \mathrm{g}^{-1} \mathrm{FW}\right)\end{array}$ \\
\hline $0 \mathrm{NaCl}$ & 1.0 & 0.1450 & $5.90 \pm 0.1^{b}$ \\
\hline $75 \mathrm{mM}$ & 1.0 & 0.0200 & $1.38 \pm 0.2^{a}$ \\
\hline $150 \mathrm{mM}$ & 1.0 & 0.0200 & $1.16 \pm 0.1^{\mathrm{a}}$ \\
\hline
\end{tabular}




\subsection{VOC Evaluation}

The relative percentage of volatile compounds in both normal and salt-stressed leaves of L. inermis analyzed by Gas Chromatography-Mass Spectrometry (GC-MS) is reported in Table 4. Almost the half of compounds were in common in all the samples (a total of 26). Each sample was separated from the others by some compounds whose number increased with the salinity concentration. These components represented $3 \%$ of the identified fraction in control plants, reached $7 \%$ in $75 \mathrm{mM}$, and overcame $32 \%$ in the samples treated with $150 \mathrm{mM} \mathrm{NaCl}$. Salt stress induced the biosynthesis of 18 new compounds at $75 \mathrm{mM}$ and 13 at $150 \mathrm{mM}$. These compounds belonged to various chemical classes. Aliphatic hydrocarbons (non-terpenes, NTs) were the major class in the control sample and in the sample stressed at $150 \mathrm{mM}$ $\mathrm{NaCl}$, accounting for $55.5 \%$ and $63.5 \%$, respectively (Table 4 ).

The aromatic compounds (total terpenes) were the second chemical class, showing almost the same percentage in control (32.4\%) and in $150 \mathrm{mM} \mathrm{NaCl}$-stressed plants (30.1\%). Plants treated with $75 \mathrm{mM} \mathrm{NaCl}$ evidenced a controversial behavior because the most important class of constituent was of the total terpenes $(50.1 \%)$ followed by non-terpenes (38.6\%). Of note was the drastic decrease in the apocarotenoid percentage with the increase of salinity. The application of $\mathrm{NaCl}$ conspicuously decreased the amount of this latter class, exclusively represented by (E)-geranylacetone, in amounts of $37 \%$ and $88 \%$ for 75 and $150 \mathrm{mM} \mathrm{NaCl}$, respectively. This decrease also affected the alcohols $(71 \%$ and $63 \%$, respectively). The variation in monoterpene hydrocarbon content with the increase of salinity is also important to mention. Their amount increased at $75 \mathrm{mM}(\uparrow 62 \%)$ and fell below the control value $(\downarrow 62 \%)$ at $150 \mathrm{mM} \mathrm{NaCl}$. The same trend was also observed in oxygenated monoterpenes $(\uparrow 36 \%$ and $\downarrow 22 \%$, respectively), total terpenes ( $\uparrow 55 \%$ and $\downarrow 7 \%$, respectively), aldehydes ( $\uparrow 41 \%$ and $\downarrow 34 \%$, respectively), and the sum of ethers and ketones ( $\uparrow 92 \%$ and $\downarrow 46 \%$, respectively). On the contrary, the number of constituents increased from 32 in the control, to 47 in $75 \mathrm{mM}$, to 51 at $150 \mathrm{mM} \mathrm{NaCl}$. Moreover, the highest $\mathrm{NaCl}$ concentration $(150 \mathrm{mM})$ induced a huge increase of alkanes $(1300 \%)$ and esters $(226 \%)$, together with the percentage of sesquiterpene compounds (194\%).

The control specimens were characterized by the highest relative abundance of (E)-3-hexen-1-ol (27.0\%), whose percentage decreased by $69.3 \%$ at the highest concentration of $\mathrm{NaCl}$, where (Z)-3-hexenyl isovalerate became the main constituent $(20.9 \%)$. Compared to the control, relative content in (Z)- $\beta$-ocimene lowered at $47.8 \%$ in $75 \mathrm{mM} \mathrm{NaCl}$ and then disappeared at $150 \mathrm{mM} \mathrm{NaCl}$, and the same occurred for $\gamma$-terpinene, $n$-eicosane, and 3-ethyl-1-hexanol. The application of $75 \mathrm{mM} \mathrm{NaCl}$ did not notably change the linalool content. However, the level of $150 \mathrm{mM} \mathrm{NaCl}$ caused a significantly negative effect on its content (a decrease of $40.7 \%$ ). In contrast, $\mathrm{NaCl}$ stress enhanced the amount of $\tau$-cadinol and methyl 3,5-di-tert-butyl-4-hydroxybenzoate.

Among the identified compounds of the leaves, nine evoked common green leaf volatiles (GLVs); in fact (E)-3-hexen-1-ol, 1-hexanol, 3-ethyl-1-hexanol, nonanal, (Z)-3-hexenyl acetate, hexyl acetate, (Z)-3-hexenyl 3-methylbutanoate, hexyl 3-methylbutanoate, and (Z)-3-hexenyl isovalerate were included. As shown in the Table 4, treatment with $\mathrm{NaCl}$ promoted a slight decrease in the total percentage of the identified GLVs, even though their number increased when compared with the control.

Principal component analysis (PCA), where the first two axes added up to $97.0 \%$ of the total variability (Figure 2A,B), showed two first macro groups, one with positive loading on PC1 and the other one with a negative loading on the same axes. Control plants and those treated with $75 \mathrm{mM}$ $\mathrm{NaCl}$ were plotted in the area of positive scoring on $\mathrm{PC} 1$, where they were divided into two bottom quadrants-control samples were plotted on the bottom right quadrant (positive loading on PC2), whilst samples exposed to medium salt stress $(75 \mathrm{mM})$ were plotted on the bottom left quadrant (negative loading on PC2). However, the only sample that scored a negative loading on PC1 was that treated with $150 \mathrm{mM} \mathrm{NaCl}$-it was on the left quadrant, thus with a positive score on PC2. 
Table 4. Chemical composition of the volatile organic compounds (VOCs) from fresh leaves of Lawsonia inermis plants grown with variable salinity concentrations. HeadSpace-Solid Phase MicroExtraction (HS-SPME) was performed on Gas Chromatography-Mass Spectrometry (GC-MS) with DB-5 capillary column. Data represent mean values of relative percentage $(n=3, \pm \mathrm{SD})$.

\begin{tabular}{|c|c|c|c|c|c|}
\hline \multirow[b]{2}{*}{ Compounds } & \multirow[b]{2}{*}{ LRI $\S$} & \multirow[b]{2}{*}{ Chemical Class } & \multicolumn{3}{|c|}{ Relative Percentage } \\
\hline & & & Control & $75 \mathrm{mM} \mathrm{NaCl}$ & $150 \mathrm{mM} \mathrm{NaCl}$ \\
\hline (E)-3-Hexen-1-ol * & 868 & ALC & $27.0 \pm 2.33$ & $6.2 \pm 0.64$ & $8.3 \pm 0.64$ \\
\hline 1-Hexanol * & 875 & ALC & $3.9 \pm 0.17$ & $2.1 \pm 0.16$ & $3.9 \pm 0.17$ \\
\hline Santolina triene & 911 & $\mathrm{MH}$ & $0.4 \pm 0.16$ & $1.3 \pm 0.14$ & $0.5 \pm 0.05$ \\
\hline$\alpha$-Fanchene & 951 & $\mathrm{MH}$ & - & $0.4 \pm 0.05$ & $0.3 \pm 0.15$ \\
\hline 6-Methyl-5-hepten-2-one & 978 & KET & $0.5 \pm 0.24$ & $1.0 \pm 0.10$ & $0.3 \pm 0.01$ \\
\hline myrcene & 993 & $\mathrm{MH}$ & $0.5 \pm 0.14$ & $1.7 \pm 0.44$ & $0.4 \pm 0.05$ \\
\hline 6-Methyl-5-hepten-2-ol & 995 & ALC & $0.6 \pm 0.05$ & $1.3 \pm 0.14$ & $0.2 \pm 0.03$ \\
\hline$m$-Mentha-1(7),8-diene & 1001 & MH & - & $0.7 \pm 0.07$ & - \\
\hline$p$-Mentha-1(7),8-diene & 1004 & $\mathrm{MH}$ & - & $1.2 \pm 0.13$ & - \\
\hline (Z)-3-Hexenyl acetate * & 1008 & EST & $7.9 \pm 0.58$ & $3.4 \pm 0.34$ & $3.3 \pm 0.34$ \\
\hline$n$-Hexyl acetate * & 1013 & EST & - & - & $0.2 \pm 0.02$ \\
\hline$o$-Cymene & 1026 & $\mathrm{MH}$ & - & $0.3 \pm 0.02$ & - \\
\hline 3-Ethyl-1-hexanol * & 1032 & ALC & $1.9 \pm 0.24$ & - & - \\
\hline 1,8-Cineole & 1036 & $\mathrm{OM}$ & & $3.5 \pm 0.37$ & $1.3 \pm 0.16$ \\
\hline (Z)- $\beta$-Ocimene & 1042 & MH & $2.3 \pm 0.32$ & $1.2 \pm 0.70$ & - \\
\hline (E)- $\beta$-Ocimene & 1053 & MH & $0.4 \pm 0.09$ & $0.5 \pm 0.05$ & $0.5 \pm 0.29$ \\
\hline$\gamma$-Terpinene & 1062 & $\mathrm{MH}$ & $0.9 \pm 0.40$ & - & - \\
\hline cis-Sabinene hydrate & 1072 & $\mathrm{OM}$ & - & $0.6 \pm 0.01$ & - \\
\hline trans-Arbusculone & 1077 & $\mathrm{OM}$ & - & $0.2 \pm 0.03$ & - \\
\hline Fenchone & 1090 & $\mathrm{OM}$ & - & $0.3 \pm 0.03$ & - \\
\hline Linalool & 1102 & $\mathrm{OM}$ & $10.8 \pm 0.63$ & $11.9 \pm 1.22$ & $6.4 \pm 0.57$ \\
\hline$n$-Nonanal * & 1104 & ALD & $5.5 \pm 0.33$ & $6.0 \pm 0.62$ & $1.8 \pm 0.19$ \\
\hline$\beta$-Thujone & 1120 & $\mathrm{OM}$ & $0.3 \pm 0.01$ & $1.0 \pm 0.07$ & $0.1 \pm 0.00$ \\
\hline 2-Ethylhexanoic acid & 1123 & EST & - & - & $1.7 \pm 0.22$ \\
\hline Camphor & 1148 & $\mathrm{OM}$ & $1.4 \pm 0.21$ & $2.0 \pm 0.21$ & $1.5 \pm 0.50$ \\
\hline Isoborneol & 1160 & $\mathrm{OM}$ & - & $0.2 \pm 0.10$ & - \\
\hline Borneol & 1169 & $\mathrm{OM}$ & $0.9 \pm 0.31$ & $1.0 \pm 0.10$ & $0.8 \pm 0.07$ \\
\hline Neo-iso-isopulegol & 1171 & $\mathrm{OM}$ & $1.0 \pm 0.06$ & $1.0 \pm 0.02$ & $0.6 \pm 0.15$ \\
\hline 4-Terpineol & 1180 & $\mathrm{OM}$ & $0.6 \pm 0.46$ & $0.8 \pm 0.08$ & $0.5 \pm 0.14$ \\
\hline$\alpha$-Terpineol & 1192 & $\mathrm{OM}$ & $2.3 \pm 0.25$ & $2.9 \pm 0.31$ & $1.7 \pm 0.26$ \\
\hline$n$-Decanal & 1206 & ALD & $4.7 \pm 0.80$ & $6.6 \pm 0.69$ & $3.3 \pm 0.13$ \\
\hline (Z)-3-Hexenyl 3-methylbutanoate * & 1233 & EST & - & - & $0.6 \pm 0.14$ \\
\hline Hexyl 3-methylbutanoate * & 1242 & EST & - & - & $1.8 \pm 0.26$ \\
\hline (Z)-3-Hexenyl isovalerate * & 1243 & EST & - & - & $20.9 \pm 2.33$ \\
\hline Linalyl acetate & 1260 & OM & $1.9 \pm 0.17$ & $1.8 \pm 0.18$ & $1.4 \pm 0.24$ \\
\hline Citronellyl formate & 1280 & $\mathrm{OM}$ & - & $0.8 \pm 0.08$ & $1.1 \pm 0.17$ \\
\hline Lavandulyl acetate & 1289 & OM & $2.1 \pm 0.13$ & $2.6 \pm 0.26$ & $1.9 \pm 0.37$ \\
\hline n-Tridecane & 1300 & ALK & - & $0.5 \pm 0.06$ & $2.1 \pm 0.59$ \\
\hline Undecanal & 1305 & ALD & - & $0.8 \pm 0.09$ & - \\
\hline Neryl acetate & 1368 & $\mathrm{OM}$ & $0.9 \pm 0.09$ & $0.9 \pm 0.09$ & $0.6 \pm 0.08$ \\
\hline Geranyl acetate & 1386 & $\mathrm{OM}$ & $2.6 \pm 0.48$ & $2.2 \pm 0.23$ & $1.4 \pm 0.42$ \\
\hline$n$-Tetradecane & 1400 & ALK & - & - & $1.0 \pm 0.05$ \\
\hline Dodecanal & 1409 & ALD & - & $1.0 \pm 0.10$ & $1.1 \pm 0.10$ \\
\hline cis- $\alpha$-Bergamotene & 1417 & $\mathrm{SH}$ & - & - & $0.6 \pm 0.06$ \\
\hline$\beta$-Caryophyllene & 1418 & $\mathrm{SH}$ & - & - & $0.6 \pm 0.19$ \\
\hline (E)-Geranylacetone & 1455 & $\mathrm{AC}$ & $9.8 \pm 1.67$ & $6.2 \pm 0.64$ & $1.2 \pm 0.34$ \\
\hline$(E)-\beta$-Farnesene & 1460 & $\mathrm{SH}$ & - & - & $1.4 \pm 0.18$ \\
\hline n-Pentadecane & 1500 & ALK & $0.6 \pm 0.08$ & $1.4 \pm 0.15$ & $7.1 \pm 0.96$ \\
\hline$\beta$-Bisabolene & 1509 & $\mathrm{SH}$ & - & - & $0.3 \pm 0.00$ \\
\hline trans- $\gamma$-Cadinene & 1513 & $\mathrm{SH}$ & - & - & $0.6 \pm 0.14$ \\
\hline Tetradecanal & 1612 & ALD & - & - & $0.5 \pm 0.09$ \\
\hline$\tau$-Cadinol & 1642 & OS & $0.9 \pm 0.31$ & $4.9 \pm 0.50$ & $2.5 \pm 1.26$ \\
\hline$\alpha$-Cadinol & 1655 & OS & - & $0.5 \pm 0.05$ & - \\
\hline Octyl ether & 1677 & ETR & $0.8 \pm 0.10$ & $1.5 \pm 0.16$ & $0.4 \pm 0.18$ \\
\hline Epi- $\alpha$-bisabolol & 1685 & OS & - & $3.1 \pm 0.32$ & $1.6 \pm 0.23$ \\
\hline n-Heptadecane & 1700 & ALK & - & $0.7 \pm 0.07$ & $0.4 \pm 0.22$ \\
\hline (E)-Conipheryl alcohol & 1727 & PP & $1.4 \pm 0.08$ & $4.3 \pm 1.68$ & $2.5 \pm 0.25$ \\
\hline$n$-Octadecane & 1800 & ALK & - & - & $0.3 \pm 0.01$ \\
\hline$\beta$-Chenopodiol & 1810 & OS & - & $0.6 \pm 0.27$ & - \\
\hline Octyl salicylate & 1816 & PP & - & - & $1.1 \pm 0.38$ \\
\hline Isopropyl tetradecanoate & 1824 & EST & - & - & $0.6 \pm 0.08$ \\
\hline$(E, E)$-Farnesyl acetate & 1843 & OS & $2.2 \pm 0.57$ & - & $1.5 \pm 0.82$ \\
\hline Methyl3,5-di-tert-butyl-4-hydroxybenzoate & 1859 & EST & $2.1 \pm 0.19$ & $5.2 \pm 0.34$ & $3.5 \pm 0.55$ \\
\hline$n$-Nonadecane & 1899 & ALK & - & $0.4 \pm 0.18$ & $0.2 \pm 0.00$ \\
\hline$n$-Eicosane & 2000 & ALK & $0.2 \pm 0.01$ & - & - \\
\hline Isopropyl hexadecanoate & 2027 & EST & - & $0.5 \pm 0.14$ & - \\
\hline
\end{tabular}


Table 4. Cont.

\begin{tabular}{cccc}
\hline & \multicolumn{3}{c}{ Relative Percentage } \\
\hline Class of Compounds & Control & $\mathbf{7 5 ~} \mathbf{~ M}$ & $\mathbf{1 5 0} \mathbf{~ m M}$ \\
\hline Monoterpene hydrocarbons & $4.5 \pm 1.11$ & $7.3 \pm 1.38$ & $1.7 \pm 0.53$ \\
Oxygenated monoterpenes & $24.8 \pm 2.79$ & $33.7 \pm 3.41$ & $19.3 \pm 3.13$ \\
Sesquiterpene hydrocarbons & $0.0 \pm 0.00$ & $0.0 \pm 0.00$ & $3.5 \pm 0.57$ \\
Oxygenated sesquiterpenes & $3.1 \pm 0.88$ & $9.1 \pm 1.14$ & $5.6 \pm 2.31$ \\
Total terpenes & $32.4 \pm 4.78$ & $50.1 \pm 5.88$ & $30.1 \pm 6.54$ \\
Phenylpropanoids & $1.4 \pm 0.08$ & $4.3 \pm 1.68$ & $3.6 \pm 0.63$ \\
Apocarotenoides & $9.8 \pm 1.67$ & $6.2 \pm 0.64$ & $1.2 \pm 0.34$ \\
Alcohol & $33.4 \pm 2.79$ & $9.6 \pm 0.94$ & $12.4 \pm 0.85$ \\
Aldehydes & $10.2 \pm 1.13$ & $14.4 \pm 1.50$ & $6.7 \pm 0.51$ \\
Alkane & $0.8 \pm 0.09$ & $3.0 \pm 0.57$ & $11.2 \pm 1.83$ \\
Ester & $10.0 \pm 0.78$ & $9.1 \pm 0.69$ & $32.6 \pm 3.94$ \\
Ether + ketone & $1.3 \pm 0.34$ & $2.5 \pm 0.26$ & $0.7 \pm 0.19$ \\
Non-terpene derivatives & $55.5 \pm 5.13$ & $38,6 \pm 3.96$ & $63.5 \pm 7.33$ \\
\hline Total Identified & $\mathbf{9 9 . 3} \pm 0.66$ & $\mathbf{9 9 . 2} \pm 0.31$ & $\mathbf{9 8 . 4} \pm 0.95$ \\
\hline
\end{tabular}

* Compounds present with abundance $\geq 0.1 \%$; ${ }^{\S}$ LRI: linear retention indices on DB- 5 column; *: green leaf volatile compounds (GLV).

A
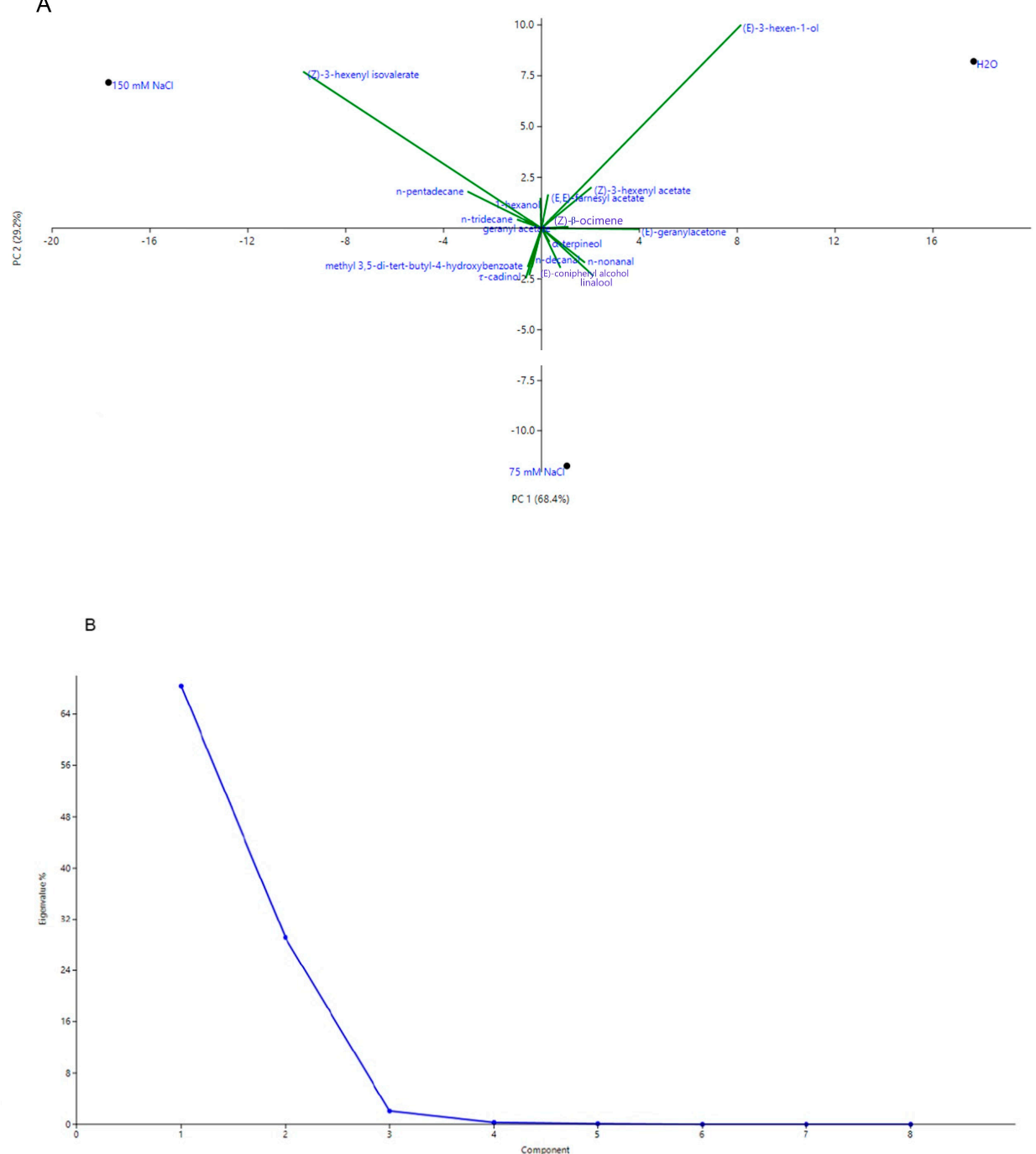

Figure 2. Scatter plot (A) and Scree plot (B) of the principal component analysis (PCA) of the volatile organic compounds (VOCs) at different gradient of salinity.

This position was due to their contents in (Z)-3-hexenyl isovalerate, which was the only variable whose loading was negative along PC1 and positive on PC2. It is important to notice that all the 
variables were concentrated around the origin of the axes, and only (E)-3-hexen-1-ol and (Z)-3-hexenyl isovalerate were more dispersed.

Hierarchical cluster analysis HCA (Figure 3), performed with the total data of the volatile composition, fit perfectly with the PCA results (Figure 2). In fact, HCA showed two different groups-A and B. Group A included only the sample at $150 \mathrm{mM} \mathrm{NaCl}$, while group $\mathrm{B}$ gathered together the control and $75 \mathrm{mM} \mathrm{NaCl}$.

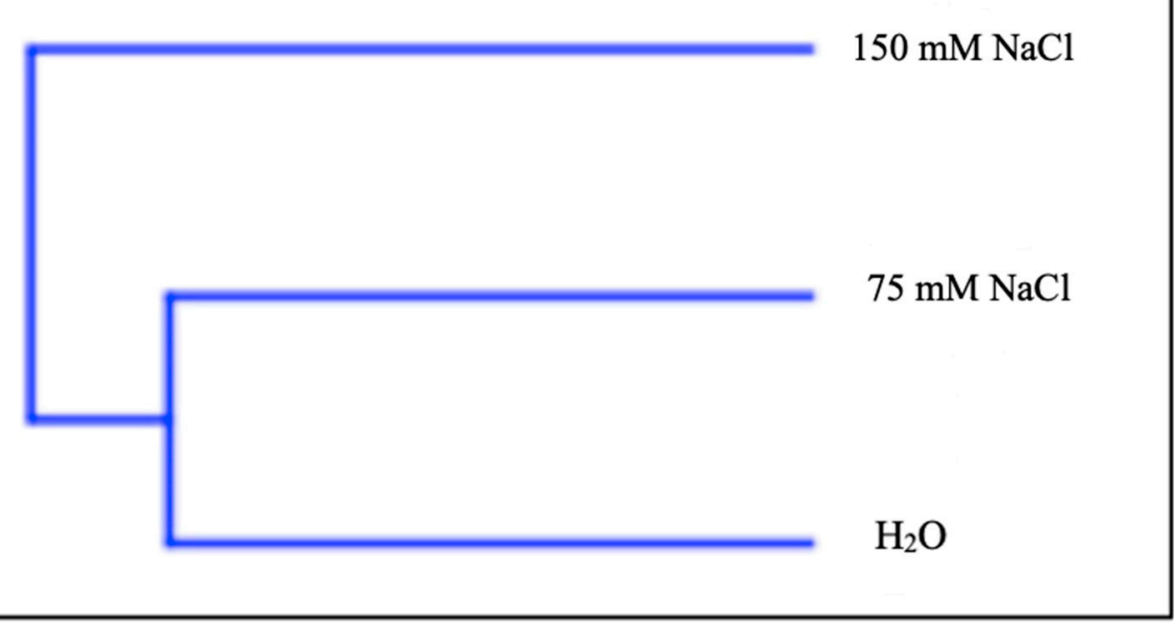

Figure 3. Dendrogram of the hierarchical cluster analysis (HCA) of the VOCs at different gradients of salinity.

The one-way PERMANOVA performed on the VOC compounds revealed significant differences among the salinity gradient $(p=0.0003)$ (Table 5$)$.

Table 5. Effect of salinity on volatile organic compounds (VOCs) according to the one-way PERMANOVA analysis.

\begin{tabular}{ccll}
\hline & $\boldsymbol{F}$ & $\boldsymbol{p}$ & Significant Pair-Wise Comparisons at $\boldsymbol{p}<\mathbf{0 . 0 5}$ \\
\hline \multirow{3}{*}{ Salinity } & 138.7 & & Control versus $75 \mathrm{mM} \mathrm{NaCl}(p=0.0291)$ \\
& & 0.0003 & Control versus $150 \mathrm{mM} \mathrm{NaCl}(p=0.0263)$ \\
& & $150 \mathrm{mM} \mathrm{NaCl}$ versus $75 \mathrm{mM} \mathrm{NaCl}(p=0.093)$ \\
\hline
\end{tabular}

According the SIMPER analysis, 13 compounds were responsible for more than $95 \%$ of this dissimilarity (Table 6), with (Z)-3-hexenyl isovalerate (39.86\%) and (E)-3-hexen-1-ol (35.99\%) being the major contributors, together covering more than $75 \%$ of the difference. 
Table 6. List of compounds responsible for dissimilarity in L. inermis spontaneous emission according to the similarity percentage (SIMPER) analysis.

\begin{tabular}{|c|c|c|c|c|c|c|}
\hline Compounds & Contribution \% & Cumulative \% & Control & $75 \mathrm{mM} \mathrm{NaCl}$ & $150 \mathrm{mM} \mathrm{NaCl}$ & $\begin{array}{c}\text { Significant Pair-Wise } \\
\text { Comparisons at } p<0.05 *\end{array}$ \\
\hline (Z)-3-Hexenyl isovalerate * & 39.86 & 39.86 & 0.0 & 0.0 & 20.9 & 1 vs. 3,2 vs. 3 \\
\hline (E)-3-Hexen-1-ol * & 35.99 & 75.85 & 27.0 & 6.2 & 8.3 & 1 vs. 2,1 vs. 3 \\
\hline (E)-Geranyl acetone & 5.28 & 81.13 & 9.8 & 6.2 & 1.2 & 1 vs. 2,1 vs. 3,2 vs. 3 \\
\hline n-Pentadecane & 3.47 & 84.60 & 0.6 & 1.4 & 7.1 & 1 vs. 3,2 vs. 3 \\
\hline Linalool & 2.45 & 87.05 & 10.8 & 11.9 & 6.4 & 1 vs. 3,2 vs. 3 \\
\hline (Z)-3-Hexenyl acetate * & 1.91 & 88.96 & 7.9 & 3.4 & 3.3 & 1 vs. 2,1 vs. 3 \\
\hline n-Nonanal * & 1.46 & 90.42 & 5.5 & 6.0 & 1.8 & 1 vs. 3,2 vs. 3 \\
\hline$\tau$-Cadinol & 1.23 & 91.65 & 0.9 & 4.9 & 2.5 & 1 vs. 2,1 vs. 3,2 vs. 3 \\
\hline 1,8-Cineole & 0.86 & 92.51 & 0.0 & 3.5 & 1.3 & 1 vs. 2,1 vs. 3,2 vs. 3 \\
\hline n-Decanal & 0.82 & 93.33 & 4.7 & 6.6 & 3.3 & 1 vs. 2,1 vs. 3,2 vs. 3 \\
\hline (E)-Conipheryl alcohol & 0.78 & 94.11 & 1.4 & 4.3 & 2.5 & 1 vs. 2,2 vs. 3 \\
\hline Methyl 3,5-di-tert-butyl-4-hydroxybenzoate & 0.68 & 94.79 & 2.1 & 5.2 & 3.5 & 1 vs. 2,1 vs. 3,2 vs. 3 \\
\hline Epi- $\alpha$-bisabolol & 0.66 & 95.45 & 0.0 & 3.1 & 1.6 & 1 vs. 2,1 vs. 3,2 vs. 3 \\
\hline
\end{tabular}

* 1: Control; 2: $75 \mathrm{mM} \mathrm{NaCl}$; 3: $150 \mathrm{mM} \mathrm{NaCl}$. 


\section{Discussion}

\subsection{Effect of Salt Treatment on Growth of Plants}

Salinity influences the growth and development of plants by limiting leaf expansion [12] and also fruit production such as in tomato [15]. In the present work, young henna plants showed a dose-dependent reduction of growth under a short-term period (up to 20 days) of salt treatment. In particular, our data showed the salt tolerance of henna plants at medium concentration of $\mathrm{NaCl}$ $(75 \mathrm{mM})$, which did not show any statistical difference in leaf number and leaf area compared to control plants. Conversely, an inhibition of growth parameters occurred at the highest salt level $(150 \mathrm{mM})$ after only 20 days of treatment. A similar reduction of leaf number and leaf area was observed in henna plants subjected to drought stress [7] and to long-term salinity treatment [10].

The reduced leaf area is considered an avoidance mechanism to minimize water loss by transpiration, together with the stomatal closure, as has already been reported for the Mediterranean plant Rosmarinus officinalis [16]. This species, like other tolerant plants, operates an osmotic adjustment to maintain its water status under salt stress, as supported by the slight reduction in RWC [16].

\subsection{Effects of Salt Treatment on Photosynthetic Parameters}

Henna plants were able to respond to salinity by maintaining unaltered values of the potential efficiency of photosystem II (PSII) photochemistry (close to 0.8) throughout the treatment period independently of the $\mathrm{NaCl}$ dose, suggesting the absence of PSII damages [17,18]. However, at severe salt stress $(150 \mathrm{mM} \mathrm{NaCl})$, a decrease of the actual photon yield of PSII photochemistry was observed after 20 days of salt treatment associated with an increase of NPQ, which furnishes an estimation of thermal energy dissipation capacity [19]. The effect of salinity stress on non-photochemical quenching parameters is dependent on plants and cultivar, increasing more substantially in the salt-tolerant than in the salt-sensitive plants [20]. These data suggest that henna plants were able to counteract the increase of excess excitation energy at PSII due to the reduced electron transport rate by increasing heat dissipation; this contributes to avoid photoinhibition and photodamage of photosynthetic apparatus under high salinity level [21]. Accordingly, henna plants showed a decrease of both $A$ and $C_{i}$ compared to control plants, supporting the hypothesis that the salt-dependent decrease in photosynthetic $\mathrm{CO}_{2}$ uptake was mainly due to stomatal factors, rather than to PSII activity reduction or metabolic impairment [22,23]. Indeed, henna plants showed a dose-dependent decrease of $\mathrm{g}_{\mathrm{s}}$ after salt treatment, in agreement with previous findings, suggesting that regulation of stomatal conductance plays an important role in the adaptation to high salinity in this species [10] and in other semi-arid adapted plants [15,24]. The partial stomatal closure reduced the leaf transpiration in henna plants, contributing to maintaining the leaf turgor potential and to reducing the influx of salt into the shoots [12]. The decrease of $A$ in henna plants was not as severe as the decrease in $\mathrm{g}_{\mathrm{s}}$ and $\mathrm{E}$, leading to an increase in both intrinsic and instantaneous WUE, especially under severe salt stress [10]. As a consequence, henna plants showed only a slight reduction of RWC under both salt treatments, similar to that observed in wheat, known as medium tolerant species [25]. Hence, our data pointed out a crucial role of heat dissipation of excess energy, stomatal control, and increase in WUE in the adaptation of henna plants to high salinity levels.

\subsection{Effects of Salt Treatment on Lawsone Production and Stress-Related Metabolic Compounds}

Henna plant is widely cultivated for the production of the lawsone, a dye used both as a cosmetic and a pharmacological agent [5]. Lawsone production is enhanced by high temperature and high light intensity [6]. Many reports have been conducted to analyze the growth condition of henna in order to achieve information on its ability to tolerate drought and salinity $[7,8,10]$. However, these authors excluded the examination of the influence of the stress for the production of lawsone. In the present work, lawsone content was determined for the first time during salinity exposition for 3 weeks. The amount found in the leaves of henna treated with different $\mathrm{NaCl}$ concentrations revealed that salinity led to a decreased production, associated with the decrease in photosynthetic activity. 
Hence, our data highlighted that the reduction in lawsone production was related to the reduced $\mathrm{CO}_{2}$ uptake under salinity treatment, essentially due to the partial stomatal closure.

Salt stress can affect the photosynthetic apparatus, leading to salt accumulation in young leaves and loss of photosynthetic pigments [26]. However, plants tolerant to $\mathrm{NaCl}$ respond to salinity by maintaining or increasing their chlorophyll content, suggesting that this parameter can be considered a biochemical marker of salt tolerance in plants [20]. Hence, the increase of total chlorophylls in henna plants with increasing $\mathrm{NaCl}$ concentration indicated a high resilience of this species to salt stress, protecting the photosynthetic apparatus from irreversible damages. In particular, the observed changes in photosynthetic pigments could be involved in the optimization of light capture and dissipation of excess energy under salt stress conditions [22,27,28]. Likewise, the NPQ increased in $150 \mathrm{mM} \mathrm{NaCl}$-treated plants, indicating the activation of the photoprotection process. This statement is supported by the increasing amount of carotenoids. Indeed, carotenoids operate an important photoprotective role by dissipating excess excitation energy at PSII as heat through the so-called xanthophyll cycle and can play a crucial role in protecting photosynthetic apparatus from photoinhibitory damage under high salinity level [21]. Moreover, under stress conditions, carotenoids also act as scavenging agents against ROS, protecting the photosynthetic apparatus from oxidative stress [29]. However, salinity tolerance is often attributed to an osmotic adjustment and the stomatal control linked to the accumulation of osmolytes or compatible solutes [12]. The closure of stomata in salt stress is well documented, and proline thus represents most important osmoprotectant agent, for which concentration is enhanced under salinity conditions [12]; this is in agreement with the data reported in henna leaves, where proline was found to be significantly greater in $150 \mathrm{mM}$ leaves. Moreover, proline can have antioxidant properties, protecting the structure of macromolecules against the dehydration process.

Under salinity conditions, one of the most common responses of plants is the accelerated generation of ROS produced in the photosynthetic process, and thus an efficient antioxidant system is needed to counteract the oxidative burst associated with ROS production [20]. Therefore, the antioxidant compounds as polyphenols, anthocyanins, and flavonoids were monitored during salt treatment in L. inermis. In agreement with the antioxidant activity (DPPH assay), anthocyanins and flavonoids were more concentrated in the highest salt treatment, while medium stress did not influence these molecules. The ability to modulate the mechanism of production of antioxidant molecules with the strength of salinity is already known in several plants [30], and L. inermis is considered a medium tolerant species to salt stress $[8,10]$.

\subsection{Emission of Leaf VOCs in Henna Plants Subjected to Salt Stress}

Plants produce volatile compounds to cope with environmental stress and avoid damage [31]. VOC release under $\mathrm{NaCl}$ stress is helpful for plants, driving the maintenance of stomatal conductance and photosynthesis [32]. The control leaves of L. inermis showed similarity with the EO composition of Tunisian henna leaves, which has already been published [33]. The presence of $\beta$-ionone, a typical compound of different henna powder and leaves, was not revealed in the VOCs of this work [34,35]. Moreover, no information is available regarding the salt effect on VOCs of L. inermis.

The leaves were rich in both oxygenated monoterpenes and alcohols, but they were negatively affected by salt stress. The same behavior was also noted in monoterpene hydrocarbons, aldehydes, and the sum of ethers and ketones. Conversely, total sesquiterpenes were enhanced at high salt concentration. Several terpenoids, such as (E)- $\beta$-ocimene, linalool, b-caryophyllene, and $(E)-\beta$-farnesene, are characteristic stress compounds in many plant species [36]. Except for the two first compounds, which were already present in the VOCs of control plants, the percentage of the remaining two was increased by the salinity stress.

Other volatile compounds belonging to esters, alkanes, and alcohols are recognized as Green Leaf Volatiles (GLVs) and are defined as a class of six-carbon (C6) compounds that play a role in plant defense against insect herbivore attack [37]. Our results revealed the presence of these compounds 
even in the control plants, although total alkanes and, especially, esters showed a growing trend with an increase in the salinity level, gradually becoming one of the dominant classes in salt-treated plants at $150 \mathrm{mM} \mathrm{NaCl}$, while the monoterpene hydrocarbons decreased. In fact, GLVs were responsible for segregating the control samples from those treated with salt, as shown in PCA analysis. A reduction of monoterpenes associated with an enhanced biosynthesis and accumulation of esters has been previously observed in Schizonepeta tenuifolia as salinity increased [38]. Moreover, it has been shown that the treatment with GLV esters induced stomatal closure in several plant species belonging to Solanaceae, Leguminosae, Brassicaceae, Citrus, and Gramineae [39]. Tomescu and co-workers [40] showed a drastic effect of salinity on the emission of some GLVs in L. esculentum leaves as a product of lipoxygenase pathway, as well as the increased emission of all terpenes in proportion to the salt concentration. It is likely that the emission of such compounds could be elicited as in response to other abiotic stresses such as high light, ozone, and high temperature [31]. It is interesting to note the significant decrease of apocarotenoids induced by salinity stress. These compounds are ubiquitous carotenoid derivatives and include volatile aromatic compounds as well as the phytohormones abscisic acid and strigolactones, which could be synthesized during the salt stress in L. inermis.

Overall, our data highlighted significant changes in VOC production in leaves of L. inermis subjected to salt stress, with an increase of specific volatile compounds such as some terpenoids, alkanes, and esters. However, further studies will need to be carried out in order to support the involvement of these compounds in the salt tolerance mechanisms of L. inermis and to unravel their interaction with the observed physiological and biochemical adaptations.

\section{Materials and Methods}

\subsection{Plant Material and Growing Conditions}

Seeds of Lawsonia inermis L. were bought from a market in Gabès (South Tunisia). Seeds were sterilized by immersion in $35 \%$ sodium hypochlorite $(\mathrm{NaClO})$ for $5 \mathrm{~min}$, then rinsed in water and soaked in $70 \%$ ethanol for $10 \mathrm{~min}$. After rinsing 3 times with distilled water, the seeds were placed in Petri dishes at $4{ }^{\circ} \mathrm{C}$ for 3 days. After this treatment, the seeds were transferred in rockwool plug trays (Grodan 105 Pro Plug) for hydroponic cultivation using Hoagland solution as a nutrient. The germinated plantlets were maintained in a growth chamber at $25 \pm 1{ }^{\circ} \mathrm{C}, 60 \pm 5 \%$ of relative humidity (RH), and under 16/8 h photoperiod provided by cool white fluorescent tubes (Philips TLM 40 W/33RS) with $100 \mu \mathrm{mol} \mathrm{m}{ }^{-2} \mathrm{~s}^{-1}$ photosynthetic active radiation (PAR). After 1 month of hydroponic culture and growing, uniformly sized plantlets were transferred into pots $(10$ pots $\times$ treatment, 1 plant $\times$ pot $)$ containing $0.45 \mathrm{~L}$ of soil composed of $45 \%$ clay, $45 \%$ sand, and $10 \%$ silt under $16 \mathrm{~h}$ photoperiod provided by cool white fluorescent tubes (Philips TLM $40 \mathrm{~W} / 33 \mathrm{RS}$ ) with $500 \mu \mathrm{mol} \mathrm{m} \mathrm{m}^{-2} \mathrm{~s}^{-1}$ PAR. The plants (approximately $10 \mathrm{~cm}$ long) were randomly divided into 3 groups (10 plants per group) for each salt stress level. Treatment was applied every other day with $50 \mathrm{~mL}$ of $0 \mathrm{mM}$ (control), $75 \mathrm{mM}$, and $150 \mathrm{mM} \mathrm{NaCl}$ for 20 days and once a week with the Hoagland solution. At the end of the trials, leaves were homogenously harvested and used fresh or stored at $-80{ }^{\circ} \mathrm{C}$, depending on the morphological, physiological, and biochemical analyses.

\subsection{Morphological Parameters}

At $0,3,10$, and 20 days after treatment, the number of leaves was recorded in each pot. The relative leaf area was measured for each plant at 10 and 20 days with a digital planimeter. Relative water content (RWC) was determined using fresh leaf discs of $1 \mathrm{~cm}^{2}$. After weighting, the leaf discs were immersed in deionized water for $24 \mathrm{~h}$ and excess water was wiped with tissue paper. Full Turgor leaf weights were recorded, and the dry masses were measured after drying at $60^{\circ} \mathrm{C}$ for $48 \mathrm{~h}$. The RWC was calculated as: $\mathrm{RWC}=[($ Fresh weight - dry weight $) /($ Turgor weight - dry weight $)] \times 100$. 


\subsection{Gas Exchange and Chlorophyll Fluorescence Measurements}

Gas exchange and chlorophyll fluorescence measurements were performed on fully expanded and exposed leaves of $L$. inermis at $0,3,10$, and 20 days after treatment with 0,75 , and $150 \mathrm{mM}$ $\mathrm{NaCl}$. Measurements were carried out using a portable infrared gas analyzer (LI-6400-40, LI-COR Inc., Lincoln, NE, USA) equipped with the leaf chamber fluorometer. Instantaneous measurements of steady-state $\mathrm{CO}_{2}$ assimilation rate $\left(\mathrm{A}, \mu \mathrm{mol} \mathrm{CO} \mathrm{Cm}^{-2} \mathrm{~s}^{-1}\right)$, stomatal conductance $\left(\mathrm{g}_{\mathrm{s}}, \mathrm{mol} \mathrm{H}_{2} \mathrm{O} \mathrm{m}^{-2} \mathrm{~s}^{-1}\right)$, intercellular $\mathrm{CO}_{2}$ concentration $\left(\mathrm{C}_{\mathrm{i}}, \mu \mathrm{mol} \mathrm{CO} \mathrm{Col}^{-1}\right)$, transpiration rate $\left(\mathrm{E}, \mathrm{mmol} \mathrm{H} \mathrm{O} \mathrm{m}^{-2} \mathrm{~s}^{-1}\right)$, actual photon yield of PSII photochemistry $\left(\Phi_{\mathrm{PSII}}\right)$, Stern-Volmer non-photochemical quenching (NPQ), and the potential efficiency of PSII photochemistry $\left(\mathrm{F}_{\mathrm{v}} / \mathrm{F}_{\mathrm{m}}\right)$ were performed between 09:00 and 11:00 a.m. under growing Photosynthetic Photon Flux Density (PPFD, $500 \mu \mathrm{mol}$ photons $\mathrm{m}^{-2} \mathrm{~s}^{-1}$ ), $\mathrm{CO}_{2}$ concentration of $400 \mu \mathrm{mol} \mathrm{mol}{ }^{-1}$, and leaf temperature of $25^{\circ} \mathrm{C}$, as reported in [41]. Intrinsic and instantaneous water-use efficiency (WUE) values were determined as $\mathrm{A} / \mathrm{g}_{\mathrm{s}}$ and $\mathrm{A} / \mathrm{E}$ ratio, respectively. Measurements of $\mathrm{F}_{\mathrm{v}} / \mathrm{F}_{\mathrm{m}}$ were performed after at least $30 \mathrm{~min}$ of acclimation in the dark. The actual photon yield of PSII photochemistry was determined as $\Phi_{\mathrm{PSII}}=\left(\mathrm{F}_{\mathrm{m}}{ }^{\prime}-\mathrm{F}_{\mathrm{s}}\right) / \mathrm{F}_{\mathrm{m}}{ }^{\prime}[42]$ at steady state, where $F_{m}{ }^{\prime}$ is the maximum fluorescence yield with all PSII reaction centers in the reduced state obtained by superimposing a saturating light flash during exposition to actinic light, with $F_{\mathrm{S}}$ being the fluorescence at the actual state of PSII reaction centers during actinic illumination. Non-photochemical quenching was determined according to the Stern-Volmer equation as $N P Q=\left(F_{m} / F_{m}{ }^{\prime}\right)-1$, where $F_{m}$ is the maximum fluorescence yield in the dark, as in [43].

\subsection{Biochemical Analyses}

Fresh leaves $(0.1 \mathrm{~g})$, homogenously sampled (20 leaves $\times$ treatment) from the mid-lamina area of the intervene zone, were used for determination of pigments (chlorophylls and carotenoids), total polyphenols, total flavonoids, and 2,2-diphenyl-1-picrylhydrazyl radical (DPPH) antiradical activity, according to the published protocols [44] using a UV-VIS spectrophotometer (SHIMADZU UV-1800). The extract was also tested with ferric ion reducing antioxidant power (FRAP) antioxidant assay to confirm the antioxidant activity [45]. Anthocyanins were extracted from $0.1 \mathrm{~g}$ of fresh leaves in ethanol/ $\mathrm{HCl}(99 / 1, v / v)$ and used to read the absorbance at $535 \mathrm{~nm}$ [46]. The total anthocyanin content was expressed as milligrams of malvin chloride equivalents (ME) per gram of fresh weight. The data presented are the mean of 3 independent replicates of the homogenously pooled sample. Proline (Pro) content was determined following Bates [47], after extraction with sulfosalicylic acid $(3 \%, v / v)$. Spectrophotometric determinations were performed at $520 \mathrm{~nm}$, using toluene as a blank.

\subsection{Lawsone Determination}

Lawsone was extracted using a method reported by Bakkali [11], with some modifications. Fresh aerial parts $(1.0 \mathrm{~g})$ of $L$. inermis related to control $(0 \mathrm{NaCl})$ and salt treatment $(75$ and $150 \mathrm{mM}$ $\mathrm{NaCl})$ were dried at $30{ }^{\circ} \mathrm{C}$ and powdered, and therein extracted with $25 \mathrm{~mL}$ of EtOH-H${ }_{2} \mathrm{O} 45 \%(v / v)$ for $20 \mathrm{~h}$ under stirring $(90 \mathrm{rpm})$. Each obtained extract solution was filtered and acidified with $50 \mu \mathrm{L}$ of acetic acid, then diluted with $25 \mathrm{~mL}$ of EtOH-H $\mathrm{H}_{2} \mathrm{O} 45 \%(v / v)$ and extracted twice in a separating funnel with chloroform $(50 \mathrm{~mL})$. The combined chloroform solutions were dried by Rotavapor (BUCHI, ITALY) at $39{ }^{\circ} \mathrm{C}$, then dissolved in methanol at a final concentration of $2.0 \mathrm{mg} \mathrm{mL}^{-1}$ and centrifuged (for $5 \mathrm{~min}$ at $1145 \times g$ ) for injection in a high-performance liquid chromatography (HPLC)-photo diode array (PDA) -electrospray ionization (ESI) -mass spectrometry (MS) system.

Quantitative analysis of lawsone was performed using HPLC-PDA/UV-ESI-MS/MS equipment composed by Surveyor LC pump and autosampler coupled with a Surveyor PDA/UV-VIS detector and an LCQ Advantage ion trap ESI-MS (THERMOFINNIGAN, San Jose, CA, USA). All henna samples and standard lawsone were injected (20 $\mu \mathrm{L}$ injection volume) on a Synergi Fusion-RP column, $4.6 \times 150 \mathrm{~mm}, 4 \mu \mathrm{m}$ particle size (PHENOMENEX, Bologna, ITALY), eluting with a mobile phase consisting of methanol (solvent $\mathrm{A}$ ) and formic acid in water $0.1 \% v / v$ (solvent $\mathrm{B}$ ) using the following 
gradients: $0-15 \min 48 \%$ A isocratic mode, $15-17 \min 48-100 \%$ A, $17-27 \min 100 \%$ A isocratic mode, $27-29 \mathrm{~min} 100-48 \%$ A, $29-3948 \%$ A isocratic mode. The elution was performed at a flow rate of $1.0 \mathrm{~mL} \mathrm{~min}^{-1}$, using a splitting system of 2:8 to MS $\left(200 \mu \mathrm{L} \mathrm{min}{ }^{-1}\right)$ and PDA $\left(800 \mu \mathrm{L} \mathrm{min}{ }^{-1}\right)$ detectors, respectively. MS experiments were performed in a positive ionization mode using ionization parameters previously reported [48] and by applying normalized collision energy $35.0 \%$ in the MS/MS experiments. $\mathrm{N}_{2}$ was used both as sheath and auxiliary gas. PDA/UV-VIS experiments were registered at 248, 289, and $333 \mathrm{~nm}$ (absorptions observed for lawsone) as preferential channels. MS data were analyzed by Xcalibur 3.1 software.

The lawsone amount in all henna samples was obtained using pure lawsone as external standard in a concentration range of $125-1000 \mu \mathrm{g} \mathrm{mL}^{-1}$. Lawsone standard solutions were prepared at 4 concentrations $\left(1000,500,250\right.$, and $\left.125 \mathrm{~g} \mathrm{~mL}^{-1}\right)$ and injected in triplicate into the LC-PDA/MS system. Area obtained from the integration of peaks recorded at $289 \mathrm{~nm}$ was used for constructing the calibration curve. A linear simple correlation was used to determine the relation between variables. For the linear regression of the standard, $R^{2}$ was 0.9632 . The lawsone amount was expressed as $\mathrm{mg} \mathrm{g}^{-1}$ of fresh material. Data were obtained by using a GraphPad Software Prism 6.0.

\subsection{VOC Analysis}

The analyses of spontaneous emission (VOCs) were performed by HeadSpace-Solid Phase MicroExtraction (HS-SPME) using a polydimethylsiloxane (PDMS)-coated fiber. Homogenous samples of fresh leaves $(2 \mathrm{~g})$ were introduced into a glass conical flask $(20 \mathrm{~mL})$ and left to equilibrate for $30 \mathrm{~min}$. The fiber was exposed to the headspace for $20 \mathrm{~min}$ at room temperature; the fiber was then reinserted into the needle and transferred to the injector of the GC-MS systems where it was desorbed. GC-MS analysis was performed by a Varian CP-3800 gas chromatograph equipped with a DB 5 capillary column $(30 \mathrm{~m} \times 0.25 \mathrm{~mm}$; coating thickness: $0.25 \mu \mathrm{m})$ and a Varian Saturn 2000 ion trap mass detector. Analytical conditions and constituent identification are cited in a previous work [49].

\subsection{Statistical Analysis}

Data were submitted to different multivariate analyses. A matrix of variance-covariance was used for the measurement of eigenvalues and eigenvectors in PCA analysis, wherein the plot was performed by selecting the 2 highest principal components (PCs). This analysis, which concerned only compounds with a significant difference between the treatments and which showed a percentage greater than $2 \%$, aimed at reducing the dimensionality of the multivariate data of the matrices whilst preserving most of the variance. The hierarchical cluster analysis (HCA) was performed using Ward's method with squared Euclidian distances as a measure of similarity to individuate possible clusters of samples in the dataset. Statistically significant differences induced by salinity on VOCs were assessed with the one-way PERMANOVA with Euclidean index similarity. The percentage contribution of each compound to the observed dissimilarity was assessed through the similarity percentage analysis (SIMPER, Euclidean distance). For each compound, the difference between different salinity gradient tested with one-way ANOVA using Least Significance Difference (LSD) test for the post hoc analysis. The ANOVA analysis was performed with SPSS software (version 21), while all other analyses were performed with Past software (version 3). Morphological and biochemical data, gas exchange parameters, and chlorophyll fluorescence were statistically analyzed by ANOVA, followed by Fisher's probable least-squares difference test with cut-off significance at $p \leq 0.05$ (letters).

\subsection{Chemicals}

Ethanol, chloroform, acetic acid, HPLC-grade formic acid, and methanol were purchased from VWR (Milan, Italy). HPLC-grade water $(18 \mathrm{~m} \Omega$ ) was obtained by a Mill-Q purification system (Millipore Corp., Burlington, MA, USA). Standard lawsone (purity 97\%) was purchased from Sigma-Aldrich (Milan, Italy). 


\section{Conclusions}

L. inermis subjected to increasing $\mathrm{NaCl}$ concentrations showed an alteration of proline, photosynthetic pigments, antioxidant compounds, and VOC emissions. The decrease in growth parameters and lawsone content in the leaves was proportional to the salt level and the consequent reduction of photosynthetic $\mathrm{CO}_{2}$ uptake due to the partial stomatal closure. Overall, the preservation of photosynthetic apparatus from irreversible damage revealed a combination of biochemical and physiological adaptation responses to the salt stress, notwithstanding the lower production of economically important metabolites such as lawsone.

Author Contributions: Conceptualization: L.P. (Laura Pistelli), A.S., L.P. (Luisa Pistelli); VOC determination: B.N.; lawsone determination: M.D.L., B.M.; biometric and biochemical data: L.P. (Luisa Pistelli); gas exchange experiments: A.S.; statistical analyses: I.M., B.N.; writing, editing, and reviewing: L.P. (Laura Pistelli), A.S., M.D.L., B.N., L.P. (Luisa Pistelli). All authors have read and agreed to the published version of the manuscript.

Funding: This work was supported by the University of Pisa personal fundings (LaP, LuP, MDL) and the Italian National Research Council (AS).

Conflicts of Interest: The authors declare no conflict of interest.

\section{References}

1. Semwal, R.B.; Semwal, D.K.; Combrinck, S.; Cartwright-Jones, C.; Viljoen, A. Lawsonia inermis L. (henna): Ethnobotanical, phytochemical and pharmacological aspects. J. Ethnopharm. 2014, 155, 80-103. [CrossRef] [PubMed]

2. Dhaouadi, K.; Meliti, W.; Dallali, S.; Belkhir, M.; Ouerghemmi, S.; Sebei, H.; Fattouch, S. Commercial Lawsonia inermis L. dried leaves and processed powder: Phytochemical composition, antioxidant, antibacterial, and allelopathic activities. Ind. Crop. Prod. 2015, 77, 544-552. [CrossRef]

3. Chakkilam, R.K.; Suneetha, Y.; Srikanth, P. Review of Lawsonia inermis (LINN.). World J. Pharm. Pharm. Sci. 2017, 6, 885-891. [CrossRef]

4. Yusuf, M. A review on phytochemistry, pharmacological and coloring potential of Lawsonia inermis. In Handbook Renewable Materials for Coloration and Finishing; Yusuf, M., Ed.; Wiley: Hoboken, NJ, USA, 2018; pp. 169-188.

5. Singh, D.K.; Luqman, S.; Mathur, A.K. Lawsonia inermis L.-A commercially important primaeval dying and medicinal plant with diverse pharmacological activity: A review. Ind. Crop. Prod. 2015, 65, 269-286. [CrossRef]

6. Yadav, S.; Kumar, A.; Dora, J.; Kumar, A. Essential perspectives of Lawsonia inermis. Int. J. Pharm. Chemical. Sci. 2013, 2, 888-896.

7. Enneb, H.; Belkadji, A.; Ferchichi, A. Change in henna (Lawsonia inermis L.) morphological traits under different deficit irrigations in the southern Tunisia. Plant Sci. Today 2015, 2, 2-6. [CrossRef]

8. Farahbakhsh, H.; Pasandi Pour, A.; Reiahi, N. Physiological response of henna (Lawsonia inermis L.) to salicylic acid and salinity. Plant Prod. Sci. 2017, 20, 237-247. [CrossRef]

9. Enneb, H.; Belkadji, A.; Ferchichi, A. Physiological adaptation of Henna plant (Lawsonia inermis L.) to different irrigation conditions in Tunisian arid region. J. Anim. Plant Sci. 2016, 26, 1026-1033.

10. Fernández-García, N.; Olmos, E.; Bardisi, E.; García-De la Garma, J.; López-Berenguer, C.; Rubio-Asensio, J.S. Intrinsic water use efficiency controls the adaptation to high salinity in a semi-arid adapted plant, henna (Lawsonia inermis L.). J. Plant Physiol. 2014, 171, 64-75. [CrossRef]

11. Bakkali, A.T.; Jaziri, M.; Foriers, A.; Vander Heyden, Y.; Vanhaelen, M.; Homès, J. Lawsone accumulation in normal and transformed cultures of henna, Lawsonia inermis. Plant Cell Tiss. Org. 1997, 51, 83-87. [CrossRef]

12. Munns, R.; Tester, M. Mechanisms of salinity tolerance. Ann. Rev. Plant Biol. 2008, 59, 651-681. [CrossRef] [PubMed]

13. Said-Al Ahl, H.A.H.; Omer, E.A. Medicinal and aromatic plants production under salt stress. A review. Herba Pol. 2011, 57, 72-87.

14. Caser, M.; D'Angiolillo, F.; Chitarra, W.; Lovisolo, C.; Ruffoni, B.; Pistelli, L.; Pistelli, L.; Scariot, V. Ecophysiological and phytochemical responses of Salvia sinaloensis Fern. to drought stress. Plant Growth Regul. 2018, 84, 383-394. [CrossRef] 
15. Moles, T.M.; De Brito, F.R.; Mariotti, L.; Pompeiano, A.; Lupini, A.; Incrocci, L.; Carmassi, G.; Scartazza, A.; Pistelli, L.; Guglielminetti, L.; et al. Salinity in autumn-winter season and fruit quality of tomato landraces. Front. Plant Sci. 2019, 10, 1078. [CrossRef] [PubMed]

16. Alarcon, J.J.; Morales, M.A.; Ferrandez, T.; Sanchez-Blanco, M.J. Effects of water and salt stresses on growth, water relations and gas exchange in Rosmarinus officinalis. J. Hortic. Sci. Biotechnol. 2006, 81, 845-853. [CrossRef]

17. Maxwell, K.; Johnson, G.N. Chlorophyll fluorescence-A practical guide. J. Exp. Bot. 2000, 51, 659-668. [CrossRef]

18. Pompeiano, A.; Huarancca Reyes, T.; Moles, T.M.; Villani, M.; Volterrani, M.; Guglielminetti, L.; Scartazza, A. Inter-and intraspecific variability in physiological traits and post-anoxia recovery of photosynthetic efficiency in grasses under oxygen deprivation. Physiol. Plant. 2017, 161, 385-399. [CrossRef]

19. Müller, P.; Li, X.-P.; Niyogi, K.K. Non-photochemical quenching. A response to excess light energy. Plant Physiol. 2001, 125, 1558-1566. [CrossRef]

20. Acosta-Motos, J.R.; Ortuño, M.F.; Bernal-Vicente, A.; Diaz-Vivancos, P.; Sanchez-Blanco, M.J.; Hernandez, J.A. Plant responses to salt stress: Adaptive mechanisms. Agronomy 2017, 7, 18. [CrossRef]

21. Qiu, N.; Lu, Q.; Lu, C. Photosynthesis, photosystem II efficiency and the xanthophyll cycle in the salt-adapted halophyte Atriplex centralasiatica. New Phytol. 2003, 159, 479-486. [CrossRef]

22. Kalaji, H.M.; Bosa, K.; Kościelniak, J.; Żuk-Gołaszewska, K. Effects of salt stress on photosystem II efficiency and $\mathrm{CO}_{2}$ assimilation of two Syrian barley landraces. Environ. Exp. Bot. 2011, 73, 64-72. [CrossRef]

23. Moles, T.M.; Pompeiano, A.; Reyes, T.H.; Scartazza, A.; Guglielminetti, L. The efficient physiological strategy of a tomato landrace in response to short-term salinity stress. Plant Physiol. Biochem. 2016, 109, $262-272$. [CrossRef] [PubMed]

24. Navarro, A.; Banon, S.; Olmos, E.; Sanchez-Blanco, M.J. Effects of sodium chloride on water potential components, hydraulic conductivity, gas exchange and leaf ultrastructure of Arbutus unedo plants. Plant Sci. 2007, 172, 473-480. [CrossRef]

25. Sairam, R.K.; Rao, K.V.; Srivastava, G.C. Differential response of wheat genotypes to long term salinity stress in relation to oxidative stress, antioxidant activity and osmolyte concentration. Plant Sci. 2002, 163, 1037-1046. [CrossRef]

26. Ashraf, M.P.J.C.; Harris, P.J.C. Potential biochemical indicators of salinity tolerance in plants. Plant Sci. 2004, 166, 3-16. [CrossRef]

27. Fusaro, L.; Mereu, S.; Brunetti, C.; Di Ferdinando, M.; Ferrini, F.; Manes, F.; Salvatori, E.; Marzuoli, R.; Gerosa, G.; Tattini, M. Photosynthetic performance and biochemical adjustments in two co-occurring Mediterranean evergreens, Quercus ilex and Arbutus unedo, differing in salt-exclusion ability. Funct. Plant Biol. 2014, 41, 391-400. [CrossRef]

28. Pompeiano, A.; Di Patrizio, E.; Volterrani, M.; Scartazza, A.; Guglielminetti, L. Growth responses and physiological traits of seashore paspalum subjected to short-term salinity stress and recovery. Agric. Water Manag. 2016, 163, 57-65. [CrossRef]

29. Peñuelas, J.; Munné-Bosch, S. Isoprenoids: An evolutionary pool for photoprotection. Trends Plant Sci. 2005, 10, 166-169. [CrossRef]

30. García-Caparrós, P.; Lao, M.T. The effects of salt stress on ornamental plants and integrative cultivation practices. Sci. Hortic. 2018, 240, 430-439. [CrossRef]

31. Loreto, F.; Schnitzler, J.P. Abiotic stresses and induced BVOCs. Trends Plant Sci. 2010, 15, 154-166. [CrossRef]

32. Loreto, F.; Delfine, S. Emission of isoprene from salt-stressed Eucalyptus globulus leaves. Plant Physiol. 2000, 123, 1605-1610. [CrossRef] [PubMed]

33. Najar, B.; Pistelli, L. Essential oil composition of Lawsonia inermis leaves from Tunisia. Am. J. Essent. Oils Nat. Prod. 2017, 5, 7-11.

34. Mengoni, T.; Vargas Peregrina, D.; Censi, R.; Cortese, M.; Ricciutelli, M.; Maggi, F.; Di Martino, P. SPME-GC-MS analysis of commercial henna samples (Lawsonia inermis L.). Nat. Prod. Res. 2016, 30, 268-275. [CrossRef]

35. Ogunbinu, A.O.; Ogunwande,I.A.; Walker, T.M.; Setzer,W.N. Study on the essential oil of Lawsonia inermis (L) Lythraceae. J. Essent. Oil Bear. Plants 2007, 10, 184-188. [CrossRef]

36. Niinemets, Ü.; Kännaste, A.; Copolovici, L. Quantitative patterns between plant volatile emissions induced by biotic stresses and the degree of damage. Front. Plant Sci. 2013, 4, 262-277. [CrossRef] [PubMed] 
37. Engelberth, J.; Alborn, H.T.; Schmelz, E.A.; Tumlinson, J.H. Airborne signals prime plants against insect herbivore attack. Proc. Natl. Acad. Sci. USA 2004, 101, 1781-1785. [CrossRef]

38. Zhou, Y.; Tang, N.; Huang, L.; Zhao, Y.; Tang, X.; Wang, K. Effects of salt stress on plant growth, antioxidant capacity, glandular trichome density, and volatile exudates of Schizonepeta tenuifolia Briq. Int. J. Mol. Sci. 2018, 19, 252. [CrossRef]

39. López-Gresa, M.P.; Payá, C.; Ozáez, M.; Rodrigo, I.; Conejero, V.; Klee, H.; Bellés, J.; Lisón, P. A new role for green leaf volatile esters in tomato stomatal defense against Pseudomonas syringe pv. Tomato. Front. Plant Sci. 2018, 9, 1855. [CrossRef]

40. Tomescu, D.; Şumălan, R.; Copolovici, L.; Copolovici, D. The influence of soil salinity on volatile organic compounds emission and photosynthetic parameters of Solanum lycopersicum L. varieties. Open Life Sci. 2017, 12, 135-142. [CrossRef]

41. Scartazza, A.; Picciarelli, P.; Mariotti, L.; Curadi, M.; Barsanti, L.; Gualtieri, P. The role of Euglena gracilis paramylon in modulating xylem hormone levels, photosynthesis and water-use efficiency in Solanum lycopersicum $\mathrm{L}$. Physiol. Plant. 2017, 161, 486-501. [CrossRef]

42. Genty, B.; Briantais, J.M.; Baker, N.R. The relationship between the quantum yield of photosynthetic electron transport and quenching of chlorophyll fluorescence. BBA Gen. Subj. 1989, 990, 87-92. [CrossRef]

43. Huarancca Reyes, T.; Scartazza, A.; Pompeiano, A.; Ciurli, A.; Lu, Y.; Guglielminetti, L.; Yamaguchi, J. Nitrate reductase modulation in response to changes in $\mathrm{C} / \mathrm{N}$ balance and nitrogen source in Arabidopsis. Plant Cell Physiol. 2018, 59, 1248-1254. [CrossRef] [PubMed]

44. Pistelli, L.; Ulivieri, V.; Giovanelli, S.; Avio, L.; Giovannetti, M.; Pistelli, L. Arbuscular mycorrhizal fungi alter the content and composition of secondary metabolites in Bituminaria bituminosa L. Plant Biol. 2017, 19, 926-933. [CrossRef] [PubMed]

45. Szőllősi, R.; Szőllősi Varga, I. Total antioxidant power in some species of Labiatae (adaptation of FRAP method). Acta Biol. Szeged. 2002, 46, 125-127.

46. Bretzel, F.; Benvenuti, S.; Pistelli, L. Metal contamination in urban street sediment in Pisa (Italy) can affect the production of antioxidant metabolites in Taraxacum officinale Weber. Environ. Sci. Pollut. Res. 2014, 21, 2325-2333. [CrossRef]

47. Bates, L.S.; Waldren, R.P.; Teare, I.D. Rapid determination of free proline for water-stress studies. Plant Soil 1973, 39, 205-207. [CrossRef]

48. Braca, A.; Sinisgalli, C.; De Leo, M.; Muscatello, B.; Cioni, P.L.; Milella, L.; Ostuni, L.; Giani, S.; Sanogo, R. Phytochemical profile, antioxidant and antidiabetic activities of Adansonia digitata L. (Baobab) from Mali, as a source of health-promoting compounds. Molecules 2018, 23, 3104. [CrossRef]

49. Najar, B.; Pistelli, L.; Cervelli, C.; Fico, G.; Giuliani, C. Salvia broussonetii Benth.: Aroma profile and micromorphological analysis. Nat. Prod. Res. 2018, 32, 1660-1668. [CrossRef]

Publisher's Note: MDPI stays neutral with regard to jurisdictional claims in published maps and institutional affiliations.

(C) 2020 by the authors. Licensee MDPI, Basel, Switzerland. This article is an open access article distributed under the terms and conditions of the Creative Commons Attribution (CC BY) license (http://creativecommons.org/licenses/by/4.0/). 